\title{
O Direito Penal dos Povos Primitivos*.
}

\author{
João Bernardino Gonzaga \\ Professor Adjunto de Direito Penal na \\ Faculdade de Direito da Universidade
}

1. O estudo do Direito Penal dos povos primitivos revela o homem em seu estado quase natural, sem o invólucro dos hábitos, necessidades, psicologia, advindos da civilização. Por isso, imersos como estamos em nosso estágio de cultura, nos é difícil compreender uma mentalidade tão diferente da que possuímos, estruturada em moldes totalmente distintos.

Falamos do primitivo de qualquer época ou lugar. Está claro que a imensa variedade de condições em que vive cada agrupamento cria um número incontável de particularidades nos respectivos modos de se organizar, de pensar e de agir. Não importa. O que procuramos fixar são certas notas próprias dos estágios iniciais da evolução social e que, por isso mesmo, se encontram na generalidade das coletividades arcaicas ${ }^{1}$.

Muitos desses sinais, diluídos embora, persistem ainda, abrigados no fundo da alma dos homens, humildes do nosso meio. Será bom que o compreendam, sobretudo os que vão desempenhar funções de Justiça dentro das camadas inferiores do povo.

\footnotetext{
*. Do curso de pós-graduação sobre História do Direito Penal, ministrado na Faculdade de Direito da U.S.P.

1. Sobre o que ocorria com o brasilíndio, ver nosso livro $O$ Direito Penal Indígena, à "Época do Descobrimento do Brasil", S. Paulo, 1972.
} 
2. Desnecessidade de Governo $e$ fatores de conservação da ordem social. Peculiaridade inicial a anotar é a escassa importância que apresenta a existência de um Governo e de uma Justiça formalmente constituídos, a ponto de não possuí-los inúmeros grupos selvagens. Habituados como estamos a ver a ordem e a segurança coletivas como produtos de todo um complexo aparelhamento preventivo-repressivo, mantindo pelo Estado, custa-nos conceber sociedades que disso prescindam, e, sem embargo, se conservem dentro de satisfatória disciplina.

Confirma-se por exemplo Robert Lowie, quando descreve a organização política de várias coletividades da África, Oceania e América do Norte (Traité de Sociologie Primitive, p. 351 e segs.). As variações que aponta são muitas: se há agrupamentos, sobretudo africanos, submetidos a chefes estáveis e alguns vivendo mesmo em regime de extremado despotismo, outros existem em que falta qualquer tipo de autoridade.

Fatores de múltipla natureza contribuem para esse último fenômeno.

O primeiro é que, realmente, as comunidades harmônicas e de âmbito restrito têm menor necessidade de organismos de supervisão. Nelas há uma vida mais rotineira, que se processa dentro de esquemas singelos e constantes. O passado orienta o presente, num apego ao tradicionalismo que desde logo gera a atrofia sobretudo do Poder Legislativo. As normas de cultura, os interesses são em linhas gerais comuns a todos os membros, de sorte que os principios de convivência, em que estão mesclados Direito e Moral, também se revestem de maior simplicidade. São principios que brotam naturalmente, por necessidades de todos sentidas, que se infiltram na consciência coletiva, e se torna fácil a sua comum aceitação. Dispensável, pois, é a presença de uma entidade que crie regras, impondo-as de cima para baixo. Os líderes que ai apareçam, em caráter permanente ou em momentos excepcionais, só se podem manter enquan- 
to coerentes com os padrões convencionais e dispõern de limitada margem de ação. Ou então, substituindo o maquinismo governamental e sem ser recebido nessa qualidade, o que freqüentes vezes se encontra é a presença de um Conselho integrado por pessoas que por qualquer motivo se destacam (geralmente a idade avançada, a maior experiência), que se incumbe de orientar as atividades do grupo, resolver de acordo com a tradição os seus problemas e ajustá-los às normas de convivência.

Acresce que em ambientes assim formados existem poderosas forças naturais de contenção, porque tudo se passa ante os olhos de todos. A opinião pública cerceia estreitamente o indivíduo e, como este depende em forte medida do bando, assume particular eficácia a reprovação social incidindo sobre aquele que se desvie dos padrões usuais de conduta. Encontra-se aqui, em diferentes condições, aquela mesma autoridade "anônima", "invisível", de que fala Erich Fromm (Psicanálise da Sociedade Contemporânea, p. 153 e segs.), que constrange cada um a manter maior docilidade aos modelos coletivos.

São exatamente enfim a simplicidade, o isolamento, a homogeneidade do grupo que mantêm o seu equilíbrio interno. Se, em vez, na comunidade, mesmo restrita, prevalece o antagonismo entre seus membros, a camada dominante só se pode manter à força da severidade e abundância dos meios coercitivos.

Quando se trata, ademais, de gente primitiva, outras circunstâncias se acrescentam.

Já tem despertado a curiosidade dos estudiosos a aparente incoerência existente no fato de que, a despeito de lhes faltar uma autoridade formalmente organizada e leis escritas que lhes imponham certo modo de vida; apesar do acentuado individualismo que nelas se encontra, as sociedades bárbaras, em vez de caírem na anarquia, se contenham dentro de forte disciplina e apego aos seus mores. Como escreve LowIE, "de modo geral, pode-se dizer que 
os indígenas observam mais facilmente as leis não escritas do Direito costumeiro que nós os artigos dos nossos códigos" (obra cit., p. 319; também Giovanni Lombard, Sociologia Criminale, pp. 53-4).

Não será difícil enumerar algumas razões do fenômeno. Há no homem primitivo forte tendência ao fracionamento em pequenos grupos e, quanto menor o grupo, mais estreitos serão os liames sociais que cercam o indivíduo.

Ele permanece, outrossim, enredado em confuso labirinto de temores. Liga-se muito fortemente ao bando, porque a vida, fora deste, se lhe torna geralmente impossível. Sente-se envolvido por elementos hostis: perigos, reais ou imaginários, da natureza, onde não pode viver isolado; riscos encarnados nas hordas vizinhas, em regra adversas, onde seria mal recebido.

Vigorando embora um regime de individualismo democrático, não se forma a noção de personalidade individual, que é substituída pela consciência social; e, pondera Kelsen, "a falta de autoconsciência, unida a uma forte consciência coletiva, dá lugar a sensibilidade muito aguda sobre o juízo da sociedade, em particular a vivíssimo temor da desaprovação pública" (Società e Natura, p. 53). Nessas circunstâncias, as prescrições costumeiras se tornam irresistíveis, porque nada se lhes contrapõe. "Os homens primitivos acreditam em magia, não porque ela dê resultado, mas a despeito do fato de que muitas vezes ela não dá resultado": é que "os mores os fazem impermeáveis à expeência". Assim, "quando os homens vivem numa comunidade em que os mores são dominantes, não podem eles nem resistir, nem criticar". "A única oportunidade que temos de ser críticos é-nos dada quando há alguma escolha entre uma formulação dos mores que contradiz outra"2.

2. Ellsworth FARIS, A Natureza e Significação dos Mores, pág. 376. Nesse sentido, também RECASÉns Siches: “Afirma-se geralmente que os povos primitivos são os mais conservadores. $O$ costume primitivo indiferenciado - que é ao mesmo tempo regulação religiosa, moral, 
De particular importância também, como força conservadora, são as exigências da reciprocidade, fruto sobretudo da interdependência que imperiosamente une os membros de um ambiente restrito. $O$ princípio do mutualismo, escreve Malinowski, "proporciona a sanção de cada regra. Em cada ato há um dualismo sociológico: duas partes que se permutam serviços e funções, do que decorre que cada uma delas cuide para que a outra cumpra sua parte do compromisso e se conduza com honradez" (Crime e Costume na Sociedade Selvagem, p. 40).

Nas descritas condições, em suma, o ser coletivo impregna e absorve a consciência do individuo, impondo-lhe naturalmente a fidelidade.

Adicione-se que, numa sociedade do tipo em exame, são entes sobrenaturais que regem os atos do indivíduo, em todos os pormenores. Os mortos lhe acompanham os passos, exigindo rígido conservadorismo. O que se vê agora não é apenas o simples hábito de manter por inércia os usos e costumes do passado (fenômeno que avulta na medida do isolamento de certo agregado humano), mas algo muito mais forte, de caráter sagrado, em que os espíritos dos que já se foram deste mundo ainda por tudo velam, a fim de impor, com prêmios e sanções, a obediência aos mores.

A religião costuma ser pobre de valores positivos, nela quase só avultando os aspectos negativos, ameaçadores. Por efeito de crenças animistas, o silvícola sente forças vi-

jurídica, política, do trato social, técnica, etc. - domina de fato com extraordinário vigor. Às vezes nem sequer é sentido como algo normativo, iras como um modo necessário de vida, até o ponto de que apenas chega a surgir a idéia de que possa ser infringido, e muito menos criticado. Desse modo, tal costume do grupo primitivo cria na mente de seus nembros uma espécie de intenso preconceito contra a mudança. Aparece como algo sacrossanto e definitivo. Se alguém se atreve - coisa rara - a julgar criticamente as regras desse costume, é considerado ímpio, e se expõe ou à expulsão da tribo ou à morte" (Tratado de Sociologia, I, pp. 325-6). 
vas nos elementos da natureza, contra os quais também cumpre acautelar-se. Sufoca-o cerrada rede de tabus, a prometerem sanções inexoráveis contra aquele que os violar. Já na infância o submetem aos chamados "ritos de iniciação", tendentes a impregnar sua inteligência, para induzi-la a mística sujeição aos antepassados e a todo o universo sobrenatural.

Não é fácil para a nossa formação cultural alcançar a eficácia que terão na mente indígena esses fatores ocultos, a exercerem permanente fiscalização e que se supõe irão operar de modo imediato, em resposta a quaisquer desvios.

Tudo se passa de modo mágico, condensado em rigido mecanismo: infringida a regra, se segue ipso facto a condenação. A má conduta e a desgraça se apresentam como o verso e o reverso da medalha.

A lei da compensação domina toda a existência do homem bárbaro. $\mathrm{E}$ este, pobre de juízo crítico, não tem fáceis meios para fugir aos rígidos esquemas da sua vida social. Eis porque, diz LÉvy-BRUHL, "o indígena observa as prescrições tradicionais como obedece às regras, muitas vezes bastante complicadas, da língua que fala: sem dificuldade, como sem reflexão. Não imagina que elas possam ser diferentes" (La Mentalité Primitive, p. 301).

À vista desses dados, já se encontra uma parte da explicação para certos fenômenos próprios das coletividades incultas : o escasso número de violações contra a ordem social interna; a desnecessidade de um Governo e de uma Justiça formalmente constituídos, bem como da cominação de sanções para inúmeros atos reprováveis; a indiferença para com procedimentos lesivos a interesses de outros grupos; a indispensável reação vindicativa contra pessoas que violem os mores, mormente se estranhas ao bando.

3. A mentalidade primitiva. Em sua obra acima citada, que já se tornou clássica sobre o assunto, LÉvy-BruHL faz observações, que em seguida resumimos, acerca da psi- 
cologia dos primitivos: eles vivem, pensam, sentem, se movem e agem num mundo que em numerosos pontos não coincide com o nosso. Sua vida compreende tão poucos incidentes, suas ocupações, pensamentos e cuidados são restritos a tão pequeno número de objetos que, necessáriamente, as idéias se tornam também muito reduzidas e limitadas. Traço que sobretudo os caracteriza é a incapacidade de fazer abstrações. Assim, sempre que possível, o primitivo substitui o raciocínio pela memória. Por isso, não formula julgamentos de valor fundados sobre a comparação positiva de idéias e objetos.

Essa inaptidão para as construções lógico-abstratas, acrescentamos - que constituem o alicerce do pensamento jurídico, é um dos motivos do profundo atraso de todas. as instituições bárbaras que dependam de tal tipo de raciocínio. E, quando consegue algum povo alçar-se nesse domínio, inclusive concatenando o seu Direito, aí está o sinal seguro de que começa a emergir do estado bruto.

Ademais, prossegue o referido autor, enquanto o homem moderno concebe o universo regido pela lei da causalidade, a mente selvagem é, em vez, essencialmente mística e prélógica; ou seja, constantemente orientada para as forças ocultas e com a maior freqüência indiferente à contradição. $O$ primitivo nada se preocupa com a procura de ligações causais que não sejam de persi evidentes. Em lugar disso, recorre a poderes místicos, de tal sorte que em suas representações se confundem o mundo sensível e o mundo espiritual. Se se interessa por certo fenômeno, não pesquisa, como os civilizados, a sua origem natural, mas imaginará de imediato, como por reflexo mental, um poder oculto e invisível, de que esse fenômeno é a manifestação.

Logo, o que chamamos de causa não passaria de inera ocasião, ou, dizendo melhor, um instrumento a serviço do sobrenatural. Eis porque, da doença e da morte aos simples acidentes, a transição é insensível. Os rústicos não vêem diferença entre a morte sobrevinda por velhice ou 
por moléstia e a morte violenta, já que nem a doença, nem o ataque de um animal, por exemplo, são as verdadeiras causas do resultado, mas estão simplesmente a serviço da força invisível que quis essa morte e que, para alcançar seus fins, teria perfeitamente podido escolher algum outro instrumento.

4. A infelicidade desqualifica. Em conseqüência do exposto, o infortúnio sempre tem, para o selvagem, um valor moral. A seus olhos, a infelicidade desqualifica. Quem é por ela atingido ao mesmo tempo decai moralmente. Objeto da cólera dos poderes invisiveis, torna-se um perigo para os seus e para o grupo social. Todos se afastam dele. Assim, exemplifica LÉvY-BruHL, em certa tribo da África, já catequizada por missionários, os indígenas que padeciam qualquer sofrimento não comungavam, por entender que isso representaria uma profanação.

Igualmente VoN Hentig, lembrando o provérbio oriental que diz: "Não tenhas nenhum negócio com o que padece desgraças". O aforisma não revela oportunismo ou failta de misericórdia, mas repousa numa crença, muito antiga, segundo a qual todo fracasso do homem encerra um sentido ético (La Pena, I, p. 111).

Lembre-se, a propósito, a importância simbólica que sempre teve sobretudo a lepra, em inúmeros povos da Antigüidade. Era doença, a um só tempo, física e moral, qual marca divina que apontava à execração seu portador.

Concomitantemente, a formação mística gera no primitivo um conformismo fatalista, que o leva a aceitar passivamente a má sorte. A desgraça equivale a uma ordália e, portanto, querer subtrair-se o paciente ao seu destino gera o risco de provocar a cólera dos espíritos. Assim, v.g., cair nas mãos do inimigo, ser feito prisioneiro, é mal comparável à moléstia, ao naufrágio, à queda de um raio, etc. Revela o rancor das forças invisíveis, sem dúvida irritadas por alguma falta da vítima. O prisioneiro escravizadu, se 
fugir, não poderá reconquistar a sua antiga posição na própria tribo. Em vez, os seus o tratarão com prudente desprezo.

5. Misticismo e lei da causalidade. $\mathrm{O}$ fato de estar o mundo selvagem tão impregnado de misticismo é forçosamente fértil de conseqüências no campo penal.

Enquanto o homem civilizado dispõe de grande massa de informações (ou no mínimo tem meios de suspeitar a sua existência), que lhe dão nítida e tranquilizadora compreensão da trama causal que governa os fenômenos naturais, - o primitivo vive perdido entre mistérios e perigos, efetivos ou supostos, para os quais não dispõe de explicações racionais. Falta-lhe outrossim segurança, porque não tem consciência das próprias forças. De conseguinte, sua formação de imagens se rege pela afetividade; e, para satisfazer o instintivo anseio de esclarecimentos, o pensamento se volta para o fantástico. $O$ fenômeno, aliás, ainda hoje pode ser comprovado. “Todas as vezes que o psiquismo é dominado pela afetividade - emoção, paixão, psicoses, —o pensamento regride à sua fase mágica" (Alves G.arcia, Princípios de Psicologia, p. 86). O mesmo sucede na infância, em que predomina a fantasia na representação da realidade.

Não será correto, todavia, pretender que ele possua mentalidade pré-lógica, no sentido de falta de harmonia e síntese na sua cultura, nem que viva à margem da lei de causalidade. Nestes pontos, acreditamos que LÉvY-BruHL mal interpretou os dados analisados em sua obra.

Magia e ciência não se justapõem numa relação de começo e fim, isto é, de sucessivos graus de conhecimento, a segunda representando um desenvolvimento da anterior. São, ao contrário, dois moldes culturais, duas estruturas de pensamento distintas, ambas intrinsecamente coerentes e completas, que trabalham em posições paralelas. Assim, o rústico, com sua fantasia criadora, concebe também um uni- 
verso harmônico e lógico, do mesmo modo que o cientista. Universo regido por ligações causais, ainda que ilusórias. E que, não dispondo de meios para localizar o encadeamento real das coisas - só possível de compreender através de dados que não lhe estão ao alcance, - sua afetividade o leva a conceber o mundo à imagem e semelhança dos próprios sentimentos, das suas emoções projetadas no ambiente externo. $O$ ponto de partida da cultura primitiva está, pois, nessa afetividade, sobre a qual entretanto repousa um raciocínio que se desdobra coerentemente. As conclusões que tira são logicamente válidas. As premissas de que partem é que se revelam falsas.

Em razão disso, mais, talvez, do que a inteligência do indivíduo moderno, o pensamento mágico sente exigências deterministas. No caso de um raio que mata certa pessoa, o homem de hoje sabe que o fato se deve ao acaso, e se satisfaz com a apreensão do curto vínculo de causa e efeito que se exaure entre os dois fenômenos. Para o selvagem, tal explicação não basta, porque é levado a procurar outras, escondidas por detrás do acontecido, nas névoas do sobrenatural. E assim como o civilizado tem consciência de que, se operar de certo modo sobre uma força geradora, se altera o curso da concatenação evolutiva, também o homem arcaico supõe que pode influir nas leis do determinismo através de uma operação mágica, ou ritual.

Aquela projeção afetiva do primitivo se torna particularmente explícita através do animismo, que acarreta a espiritualização de toda a natureza. Em cada coisa, viva ou não, se pode esconder uma alma; a qual, ademais, dispõe de amplas possibilidades de transmigração. Não há, portanto, diferença essencial entre os seres, menos ainda entre aqueles dotados de movimentação - homens e animais.

Disso decorre toda uma peculiar formação mental, cujos raciocínios e conclusões se tornam totalmente desconcertantes, se apreciados dentro da lógica moderna. KELSEN, 
por exemplo, refere que os indigenas australianos, ao verem pela primeira vez um homem a cavalo, supuseram que este fosse a mãe daquele. Porque, em sua tribo, as mulheres costumavam carregar os filhos atados às costas (obra cit., p. 52). Fato semelhante ocorreu no Sul do Brasil: quando lá chegaram os espanhóis, manifestaram os habitantes muito medo dos cavalos, "e rogavam ao governador lhes dissesse que não se aborrecessem" (CABEZA dE VACA, Naufragios y Comentarios, p. 178).

Como pouco se preocupa com as vinculações objetivas, o indivíduo inculto facilmente substitui o real pelo imaginário, sendo capaz de sinceramente admitir como verdadeiro algo cuja inexatidão esteja diante dos seus olhos. É o que explica, entre outras curiosas atitudes, certos gestos de absurda cortesia: quando alguém lhe pede uma informação, muitas vezes não responde aquilo que sabe ser correto, mas o que supõe mais agradará ao intelocutor (hábito que ainda mantém vestígios em nosso caboclo atual).

De igual maneira, a firme crença num sobrenatural permanentemente imiscuído nos negócios humanos justifica a absoluta confiança que os povos primitivos têm nas ordálias, de que sempre fizeram freqüente emprego. Tão arraigada foi essa prática, que se projetou por muitos séculos da nossa civilização ${ }^{3}$.

$\mathrm{O}$ mesmo se pode dizer quanto à chamada morte por encantamento. Modernamente não se duvida da eficácia de certas práticas malignas, em que o desfecho letal efetivamente sobrevém por efeito de mecanismo psico-fisiológicos que sofre o paciente, em decorrência da sincera per-

3. Consiste a ordália, ou julgamento de Deus, em a Justiça provocar a manifestação divina, a fim de saber se é ou não culpado por crime alguém que, suspeito embora, afirma sua inocência. Por exemplo, atirava-se o sujeito às águas, de pés e mãos atados: se sobrevivesse, aí estaria o seguro sinal da ausência de culpa. Sobre o assunto, ver - minucioso estudo feito por LAdISLAo THOT, em Historia de las Antiguas Instituciones de Derecho Penal, "Arqueología Criminal", La Plata, 1940. 
suasão sobre o valor da magia, de que estão imbuídos ele, o agente do malefício e toda a cultura em que se acham imersos.

Também se coaduna com a descrita formação mental a ausência de gratidão, muito comum entre gente rude e que tanto choca o devotamento de missionários: a cura de moléstias, ou qualquer ajuda, não representam mérito pessoal do benfeitor, que apenas age como instrumento de poderes ocultos.

6. Os tabus. Como estamos vendo, "contrariamente ao que durante muito tempo se acreditou, a alma primitiva não é uma alma simples, mas cheia de complicadas relações e pressupostos" (Sebastian Soler, Derecho Penal Argentino, I, p. 92).

Outro produto direto da formação psíquica do selvagem são os tabus que governam o comportamento individual-social. Os tabus, para Freud, constituem "uma série de restrições a que se submetem os povos primitivos; isso e aquilo são proibidos, nem eles mesmos sabem por que, nem se preocupam sequer com investigá-lo e, considerando tudo perfeitamente natural, submetem-se às restrições e estão convencidos de que a violação lhes atrairia automaticamente os piores castigos" (Totem e Tabu, p. 42). Tais restrições ,adverte, "são algo muito distinto das proibições puramente religiosas ou morais. Não emanam de nenhum mandamento divino, mas proíbem por si próprias". Assim, "carecem de todo fundamento; são de origem desconhecida; incompreensíveis para nós, parecem lógicas para aqueles que vivem sob o seu domínio" (pp. 37-8).

Originariamente, a punição ligada à sua infringência foi "entregue a uma força interior que havia de atuar de modo automático. $\mathrm{O}$ tabu violado vinga-se a si mesmo. Mais tarde, quando começa a constituir-se a representação da existência de deuses e demônios, com os quais o tabu entra em relações, espera-se do poder divíno uma punição auto- 
mática. Em outros casos, e, provavelmente, em conseqüência de um desenvolvimento ulterior dessa noção, toma a sociedade a seu cargo o castigo do atrevido, cuja falta atraiu o perigo sobre os seus parceiros. De modo que -conclui Freud - os primeiros sistemas penais da humanidade se ligam ao tabu" (p. 40). Certo é que "a transgressão de certas interdições do tabu significa um perigo social e constitui um crime que deve ser castigado ou expiado por todos os membros do grupo, sem o que virão a sofrer todos as suas conseqüências" (p. 62).

O citado autor dá, para o fato, interpretação puramente psicanalítica: o perigo que emana da quebra de um tabu será, a seu ver, entendido se "substituirmos os desejos inconscientes por impulsos conscientes". Está esse perigo "na possibilidade de uma imitação que teria por conseqüência a dissolução do grupo. Deixando os outros impune a violação, confessariam sem querer o desejo de fazer o mesmo que o culpado fez" (pp. 62-3).

Vilfredo Pareto, a seu turno, lembra que, ao depararmos com certo tabu, lhe queremos desde logo atribuir alguma razão lógica, quando em verdade ele pode não ter nenhuma, ou ser diferente daquela que imaginamos (Traité de Sociologie Générale, I, p. 592).

Haverá, nessas opinióes, alguma coisa a retificar ou acrescentar. O tabu, é exato, se pode apresentar tanto como algo que encerra uma utilidade visível (ainda que só correta dentro da mentalidade dos que nele crêem), como se revelará qual imperativo puramente gratuito, que cumpre obedecer, por motivos não racionalizados, mesmo porque é sempre garantido o castigo emergente da sua violação. Mas, como pano de fundo dessa rede de mandamentos estão solicitações emotivas calcadas no sobrenatural. Por isso, ligam-se de preferência a fenômenos mais carregados de caráter afetivo (nascimento, morte, puberdade, casamento, procriação, etc.).

São os entes espirituais que os tutelam e velam pela sua observância. Neste sentido, os tabus se apresentam como 
imposições do mundo invisível, ou, se se quiser, a sua inspiração será "divina". Muitos deles são imperativos somente em decorrência da sua índole mística. Outros terão a sua fonte geradora na sabedoria intuitiva acumulada durante gerações, em que a experiência foi sentindo o caráter prejudicial ou vantajoso de certas atitudes, aos poucos transformadas em regras, negativas ou impositivas, de conduta. Paulatinamente, assim, penetram e passam a integrar os mores do grupo, compondo a sua filosofia social.

Mas o aspecto que mais importa realçar, numa apreciação do valor jurídico do fenômeno, é este.

Enquanto para o pensamento civilizado existem planos - o mundo natural e o mundo normativo; a ordem lógica e a ordem moral - superpostos, interligados, mas que se apresentam inconfundiveis, - para o homem primário há completa e substancial interpenetração de concepções.

Se o mundo não está regido por leis puramente vaturais, neutras, de causalidade cega; se o inteiro universo, inclusive em pormenores, é manipulado, orientado, tangido por idéias-valor que se inserem num planejamento que em tudo se revela, - daí se segue a total confusão entre os mundos físico e normativo, entre as ordens natural, moral e social.

A própria natureza, com suas forças ocultas e inteligentes, se apresenta como legislador e ministrador da "justiça". Aquilo que se acredita representar sua vontade fica transformado em tabu, que não pode deixar de ser obedecido.

Aqui, portanto, encontramos inserido todo um Direito Penal enigmático, místico, para nós incompreensível. A quebra de certo tabu acarretará conseqüências inexoráveis e automáticas para o agente. Mas pode também suceder que sobrevenha um risco para toda a coletividade, sobre a qual recairá a vingança dos espíritos ofendidos. $\mathrm{E}$ então é preciso punir o culpado, ou porque criou a possibilidade de um mal generalizado, ou porque, tomando-se a iniciativa do seu castigo, se aplacam as iras da divindade ultrajada. 
Também em razão do exposto decorre a enorme dificuldade de fazer-se o catálogo dos procedimentos puniveis, numa comunidade bárbara, porque o seu campo é nuito flutuante, sobretudo no amplo setor em que a noção de "crime" se liga à de desobediência a tabus.

E que, primeiro, varia de grupo para grupo esse campo, na dependência das respectivas condições de vida, dos costumes, das crenças existentes, etc. A seguir, por outra ordem de consideração. Hoje, tendo como fonte inspiradora certos valores a priori reconhecidos, o legislador indica as ações típicas que merecem pena. Algo equivalente também faz o silvícola, admitindo que determinadas maneiras de proceder representam ofensas a algum tabu, ou aos mores do grupo, e que, portanto, justificam um castigo. Mas, freqüentemente, ele segue caminho inverso. Isto é, presente um infortúnio (seca, escassez de caça, derrota em combate, etc.), acredita que tal seja resultado de alguma conduta reprovável, que procura identificar através de critérios empírico-supersticiosos. Assim, em inúmeros casos encontramos o que em linguagem modernizada chamariamos de tipos criminais completamente abertos: será delituosa qualquer ação que eventualmente, em certa conjuntura, se reputar responsável pelo desencadeamento das forças mágicas.

7. O problema da responsabilidade penal. Atualmente, só se justifica a aplicação da lei penal quando se apresenta algum malefício na realidade objetiva; e a responsabilização pelo mesmo descansa em juízo de censura que depende do preenchimento de rigorosos requisitos: haver pessoa mentalmente capaz de merecer reprovação, na hipótese vertente (imputabilidade). A seguir, pessoa ligada ao mal ocorrido, em regra por duplo vínculo - de causalidade física, estabelecendo um nexo entre alguma sua conduta livre e aquele evento; de causalidade psíquica, que faça aparecer a ofensa como projeção de certa atitude espiritual, traduzida em dolo ou culpa (culpabilidade). 
Logo, o Direito moderno só se interessa por ações humanas; e exclusivamente o ou os efetivos responsáveis podem pagar por um crime, jamais terceiros inocentes (princípio da personalidade da responsabilidade criminal).

Tudo isso parece hoje elementar, porque representa, para a nossa formação cultural, postulados intuitivamıente justos, de que se deve impregnar a ordem jurídica; e o progresso da nossa disciplina tem precisamente consistido no contínuo aperfeiçoamento das citadas exigências. Espanta ver, no entanto, o quão recente é o domínio dessas idéias na história da humanidade.

Se recuarmos algumas poucas centúrias, já encontraremos a Justiça organizada em estruturas lógicas mui distintas. Imiscuia-se com largueza o Poder sancionador nos domínios da estrita consciência individual, enveredando por extremado subjetivismo. Ou, ao inverso, o fato de se ter apresentado algum dano justificava formas aberrantes de responsabilização. Alheava-se a Justiça às idéias de imputabilidade ,culpa, causalidade objetiva. O fenômeno se explica por uma série de razões morais, religiosas, culturais, políticas, etc., que não importa averiguar aqui. Mas pôde persistir e teve aceitação popular porque representava também a sobrevivência de formas arcaicas de reação contra o crime, profundamente enraizadas em imemoriais costumes e nos instintos humanos. Notadamente, como resíduo da vingança privada, da lei de compensação e de primitivas concepções místicas.

A vingança privada tende fatalmente à responsabilidade objetiva; assim como à responsabilidade comunicante, transmissivel a terceiros, e chega sempre à responsabilidade coletiva. Por motivo de um dano sofrido, a reação se exerce, se possível, contra aquele que o produziu. Mas pode também resvalar pelo causador do mal e alcançar diferentes pessoas, a ele ligadas por laços de solidariedade familiar, totêmica, social, etc. Impera a lei da compensação, a funcionar uneca- 
nicamente, como regra absoluta, indispensável e cega. Pouco importa averiguar se houve ou não culpa moral por parte do sujeito contra o qual ela se executa.

Eis porque, assinala FAUconNET, "a instituição da vendetta não pode atuar, desenvolvendo todas as conseqüências de seu princípio, senão em sociedades de determinada estrutura: é preciso que os grupos domésticos, fortemente integrados, sejam completamente independentes uns dos outros, ou muito tenuamente federados. Porque, de um lado, a vendetta é uma obrigação essencialmente doméstica e, de outro lado, toda organização política forte tende necessariamente a destruir um regime endêmico de guerras privadas: o desencadeamento de vinganças ilimitadas ameaçando constantemente de dissolução a federação de famílias que elas põem em confronto. A limitação da vendetta é, pois, uma das manifestações principais do progresso político" (La Responsabilité, p. 122).

A supressão, todavia, não se faz com facilidade. Resíduos do seu sistema persistiram em manter-se ocultos, e atravessaram os séculos.

Também as sanções penais por faltas de índole religiosa nasceram em ambiente de responsabilidade objetiva, do que só aos poucos e mui arduamente a humanidade Iutou por libertar-se. A sua origem está no primitivo pensamento místico, em que se impunha apaziguar a divindade ultrajada, investindo contra o portador de determinada impureza. Em certos casos, a infringência de algum tabu representava como que infecção contagiosa, que se podia propagar àqueles que com o seu portador mantivesse contato, ou que com ele possuíssem determinados vínculos. Sobrevivência disso, por exemplo, é a passagem em que, preso ainda à concepção divina do soberano, o Livro $V$ das nossas Ordenações Filipinas compara o crime de lesa-majestade à lepra, de modo, acrescenta, que não só condena o que o comete, mas "empece e inflama os que de sua linha descendem, posto que não tenham culpa". 
Assim, será remontando à mentalidade primitiva, onde se vão encontrar as matrizes das quais se originaram essas concepções, que compreenderemos muita coisa do que se passou com o Direito Penal em sua longa trajetória.

Se penetrarmos no pensamento bárbaro, para aí localizar as fontes primeiras da atividade repressiva, nos encontraremos em outro mundo, totalmente diverso do nosso. 0 mundo da magia, que tudo encobre e por tudo se infiltra, qual denso nevoeiro.

A magia, consoante Frazer, repousa sobre dois erros lógicos principais: a) imitando o efeito desejado, se pode produzir esse efeito ("magia homeopática, ou de imitação"); b) as coisas que estiveram em contato num certo momento podem, quando separadas, agir uma sobre a outra, como se o contato não houvesse cessado ("magia de contágio"). Os resultados produzidos por essas crenças sempre foram lamentáveis. "Entre os povos primitivos, particularmente na África, uma morte natural foi geralmente, ou mesmo regularmente atribuída aos efeitos de magia malfezeja e de ordinário se vingou essa morte sobre um culpado imaginário, na realidade inocente (Magie et Religion, p. 195).

Para a mentalidade primitiva, a ocorrência de qualquer mal, individual ou coletivo, inclusive oriundo de fenômenos da natureza, induz a procurar o responsável. "O homem primitivo faz decorrer os eventos que quer compreender não de elementos da mesma espécie, mas de elementos de espécie diversa, não de um objeto, mas de um sujeito, não de uma coisa, mas de uma pessoa. Quando quer explicar algo, não pergunta: “Como ocorreu isto?". Mas: "Quem o fez?". Por exemplo, em épocas de seca, não procura o que, mas quem impede a chuva de cair. "Toda vez que o homem primitivo quer explicar um novo acontecimento, que antes lhe era desconhecido, começa por atribuí-lo a uma pessoa, ou, se esta não é visível, a um espírito" (Kelsen, obra cit., pp. 75-6). 
Apega-se em regra a alguma destas três hipóteses: a) alguém produziu o dano por meios mágicos; b) ou certa pessoa, ao causá-lo materialmente, agiu como simples instrumento de forças ocultas, oriundas diretamente dos espírítos ou de processos mágicos desencadeados por terceiros; c) ou, ainda, o malefício teve imediata origem no mundo scobrenatural (quiçá devido à infringência de algum tabu), hipótese em que pode ser necessário propiciar os entes superiores, punindo o suposto culpado, ou oferecendo-lhes algo em holocausto, como um animal ou um ser humano.

Seja como for, primeira conseqüência dessas crenças é permanecer sempre abandonado na sombra o problema do vínculo de causalidade material, que se apresenta com escassa significação. De início, por ser em muitos casos irrelevante a visível circunstância de que certa pessoa tenha produzido a lesão, já que o verdadeiro responsável pode não ser esse causador, mas outrem que dele se valeu como intermediário. A seguir, porque mesmo quando nenhuma ação humana se vislumbra como razão direta e material da ofensa, daí não se segue a inexistência de responsáveis.

Outro fator a influir decisivamente na solução que o selvagem dá ao assunto é o princípio da compensação, que envolve e contém a idéia de vingança. A mancha de sangue unicamente se extingue com sangue. Impõe-se sempre uma reação expiatória - contra o autor, efetivo ou suposío, do mal, ou contra terceiros a ele associados. Tal irresistível anseio de anulação da ofensa talvez se possa explicar pela inconsciente necessidade de manter o equilíbrio na natureza. Mas geralmente é racionalizado pelo primitivo como imposição do mundo espiritual, que orienta e fiscaliza os negócios humanos.

Esse princípio tudo domina, por tudo se insinua. Caracteriza-o a convicção de que toda lesão exige lesão equivalente. Sua natureza aliás é dupla: não só significa que uma perda sofrida por alguém deve ser compensada com outra perda igual, mas, num segundo momento histórico, passa 
também a abranger a idéia de que qualquer vantagem recebida deve ser paga com outra vantagem correspondente. Ele aparece pela primeira vez ao homem bárbaro na drástica forma da "lei de talião". São observações de KeLSEN (obra cit., p. 97 e segs.), que, à p. 108 e segs., mostra como a inteira vida individual, social, religiosa, etc., dos ambientes arcaicos é sempre regida por essas regras. "O homem primitivo age com base no princípio da compensação em todos os casos em que recebe o bem ou o mal ou o inflige a outrem, e o seu comportamento é perfeitamente igual quando se dirige a um membro do próprio grupo ou a membro de grupo estranho, a um homem ou a um animal, a planta ou a objeto inanimado, ou a uma divindade" (p. 108).

Para atuar a compensação, basta que, aos olhos do paciente, a ofensa tenha sido injusta. Por esta deve pagar alguém, mas a escolha do responsável precinde dos requisitos da causalidade objetiva e da culpabilidade. Só importam a realidade do dano e o seu vulto. A direção, já advertia Steinmetz, não é elemento essencial à vingança. A idéia que a orienta é só a de neutralizar o mal sofrido.

Assim, entre uma infinidade de exemplos, esta acorrência aludida por LowıE: em determinada povoação indígena, um menino morreu queimado pelo fogo que certa mulher acendera a fim de esquentar a água de limpeza. Embora a mulher nenhuma culpa tivesse, exigiu-se em troca a vida do seu filho (obra cit., p. 392).

8. 1mputabilidade e culpabilidade. Não se preocupa pois o homem primitivo com a verificação da culpabilidade. Em regra, a reação expiatória se faz em termos estritamente objetivos.

Como escreve LÉvY-BruHL, a infração gera suas conseqüências independentemente das intenções do agente, de maneira pode-se dizer automática. A chuva não cai, sobrevém uma tempestade, a caça desaparece, não porque, v.g., 
certa gestante provocou o abortamento, mas porque, sobrevindo este, ela não observou os tabus necessários. Pouco importa que o seu ato tenha ou não sido intencional.

Melhor ainda. "A ausência de intenção, por parte daquele que se torna culpado de uma infração, constitui mais propriamente circunstância agravante do que escusa. Nada sobrevém por acaso. Logo, como se pode ter dado que tal homem haja sido assim conduzido a praticar sua falta sem querê-la e sem o saber? Seguramente ele já será vítima de um poder oculto, ou objeto de certa cólera que se deve amansar, salvo - hipótese ainda mais grave — se esconde em si próprio, à sua revelia, algum princípio malfazejo. Em lugar pois de se sentir tranquilizado pelo fato de que ele não podia conhecer sua falta no momento em que a cometeu, e que esta, em conseqüência, era inevitável, sua inquietação redobra. Torna-se indispensável, agora, procurar: (em geral pela advinhação) o motivo pelo qual ele foi colocado em situação tão perigosa" (obra cit., pp. 308-9).

Mesmo quando se patenteia a causa de um crime, o pensamento rude o interpreta de maneira surpreendente. As razões - fome, cólera, ciúme, amor, etc. — saltam aos olhos. Os homens primitivos as percebem, como bons observadores que são. Mas, a seu ver, tais motivos não passam de condições secundárias, que nada explicam. Se alguma árvore cai esmagando alguém, não foi essa queda a verdadeira causa da morte. A árvore matou porque algum feiticeiro a havia "condenado", de sorte que ela se apresenta como mero instrumento para a execução do malefício. Igualmente, o individuo que assassina seu rival obedece a uma paixão, mas aí não estará a real origem do ato. Esta deve ser procurada alhures: "A verdadeira causa pertence sempre ao mundo invisível. O homem é ao mesmo tempo culpado e vítima (as duas noções não se distinguem na mentalidade primitiva, como sucede para nós). Se aquela causa consiste num princípio que habita nesse homem, ele é um portador 
de azar, feiticeiro, e a acusação fatal nảo tardará a formular-se" (idem, pp. 309-10).

Independendo pois a condenação criminal de se verificarem os nexos de causalidade objetiva e subjetiva; visto que quase tudo se pode resolver através de relações mágicas vinculantes e geradoras da responsabilidade, - $a$ fortiori nenhuma relevância deverá ter o requisito da imputabilidade. Nenhuma atenção merecerá o fato de se achar o agente eventualmente, no momento do crime, privado de discernimento e vontade. Melhor, em casos tais, isso até mesmo irá talvez confirmar as suspeitas existentes a seu respeito.

O estado de coação, a embriaguez, os distúrbios emocionais, não podem, via de regra, constituir motivos de desculpa. Nem as anomalias mentais, que se apresentam, para o homem primitivo, plenas de misteriosas significações. Sequer o sono importa, porque leva o indivíduo a entrar em contato com o mundo espiritual e, assim, se supõe que mais facilmente conseguirá induzir outrem a praticar algum malefício.

De igual modo, em principio nenhuma diferença existe com fundamento no sexo ou idade do agente responsabilizado pela falta. $\mathbf{E}$ comum, entre povos rudes, cercar-se a mulher de valor místico, por suas funções geradoras, o que às vezes constitui motivo para nela ver maior fonte de perigos. Também as crianças sempre foram normalmente responsabilizadas nas sociedades pré-letradas, inclusive devido à suposição de que nelas podia estar encarnado algum adulto já falecido. $O$ menor é alcançado pela reação vindicativa, ou como responsável direto do crime, ou porque envolvido nas malhas da responsabilidade coletiva.

Por fim: a vingança do selvagem se exerce até contra animais, plantas e quaisquer coisas inanimadas. Exige-o a lei da compensação, reforçada neste passo por naturais impulsos reativos oriundos dos subterrâneos da mente, e pelas crenças animistas, mercê das quais tudo, na natureza, 
pode ter uma alma. Aliás, interessante é que, em vez de definhar, o fenômeno aumentou com o progresso da civilização: a responsabilização penal de animais, sobretudo, não só foi comum entre os povos cultos da antigüidade, mas continuou mesmo a crescer depois, até atingir o apogeu no Ocidente já cristianizado.

9. Responsabilidade coletiva. Sob a égide dessas idéias todas, forçosamente o primitivo se vê tangido para os domínios da responsabilidade coletiva, em que se nivelam num mesmo tratamento culpados e inocentes.

A falta de consciência da personalidade individual; os vários laços que estabelecem forte coesão social; coesão inclusive de natureza mágica, totêmica; fatores vários, enfim, fazem com que cada membro se confunda com o grupo a que pertence. Não é concebível um homem isolado na própria individualidade. $O$ indígena é sempre indestacável do seu grupo. Há círculos concentricos de coletividades que se superpõem - a família, a aldeia, o clã, a tribo, o totem, - cada uma delas apresentando-se qual massa uniforme, em que se dissolvem as pessoas. Sente-o também o indivíduo, com respeito a si próprio, ligando-se à comunidade e aderindo à consciência social.

Convencido, diz Kelsen, "de que as qualidades morais sejam substância, o homem primitivo chega a crer que o mal, como a moléstia, é contagioso. Logo, a culpa de um indivíduo assume caráter coletivo, porque necessarianıente se estende àqueles que vivem com o culpado ou com ele mantêm estreitos vínculos sociais. Por esse motivo a responsabilidade coletiva tem tanta importância para a ordem legal primitiva. Um homem primitivo acha absolutamente óbvio que a vingança se exerça sobre todo o giupo, não obstante o delito tenha sido cometido por um só mem. bro, e considera justo que os filhos e netos paguem o tributo pela culpa dos ascendentes. Isso porque o pecado, como a moléstia, é uma substância, e se torna portanto con- 
tagioso e hereditário" (obra cit., pp. 37-8). Prova-o, continua, referindo-se inclusive a algumas tribos sul-americanas, o costume que às vezes se encontra de submeter ao mesmo tratamento, em caso de moléstia, não só a pessoa doente, mas também todos os membros da sua família.

Atua assim a solidariedade grupal, profundamente arraigada na mentalidade bárbara, tanto no sentido ativo como no passivo: a ofensa dirigida a uma pessoa alcança a inteira comunidade a que ela pertence, de sorte que a vingança se deve exercer por todos; e responsáveis, à sua vez, serão tanto o autor da lesão quanto os do seu grupo. A única exceção está forçosamente constituída pela hipótese de se defrontarem dois sujeitos de um mesmo círculo, caso em que o problema se torna só individual: ou o chefe acaso existente naquele ambiente interno pune o culpado, ou tudo se resolve entre as duas pessoas interessadas.

A sanção coletiva se infiltra por toda a história da humanidade, inclusive porque representa tendência irracional do ser humano, que a civilização a custo sufoca. Ainda hoje, sempre que se encara algum ofensor na sua qualidade de membro de certo grupo, o ímpeto natural é fazer com que a reação alcance terceiros a ele ligados. Às vezes, tal poderá ocorrer pela latente suspeita de que o malefício a todos aproveitou, ao menos moralmente, de sorte que todos devem por ele pagar. Mais comumente, todavia, essa propagação da vindita se apresenta de forma puramente automática.

10. Sançôes. Após tudo quanto já foi visto, pouco será preciso acrescentar sobre o sentido da repressão penal no tipo de sociedade que nos importa.

Entende-se modernamente que na pena se devem coordenar os seguintes escopos: justa retribuição pelo fato reprovável, em obediência aos imperativos éticos que devem ser mantidos e reforçados na consciência coletiva; a prevenção geral, que visa, através da cominação e aplicação 
de sanções, atemorizar a generalidade dos membros do agregado, convencendo-os a se absterem da prática de crimes; a prevenção especial, com o objetivo de neutralizar as tendências malfazejas acaso existentes em certo condenado - afastando-o definitiva ou temporariamente da vida social, amedrontando-o, para que de futuro não mais viole a lei, ou (finalidade superior) corrigindo-o efetivamente.

Com exceção da última, a de obter a regeneração do faltoso, todas essas idéias também se encontram nas comunidades primitivas, de modo explícito ou implícito. Como declara Durkheim, "entre a pena de hoje e aquela de antigamente, não há um abismo", porque se equivalem suas funções e elementos essenciais (De la Division du Travail Social, p. 52 e segs.).

De parte do indivíduo, existe o instinto de reação contra atos prejudiciais aos seus interesses. Não só a mera auto-defesa própria de todos os seres vivos e que Alimena confunde equivocadamente com a origem da Justiça Penal (Principii, I, p. 71), — mas reação que se volta também contra as agressões passadas, quicá em obediência a inato senso de justiça ou que, psicologicamente, poderá talvez ser explicada pelo sentimento de inferioridade de que fica tomado o ofendido e que só pode ser anulado mediante a colocação do ofensor em equivalente ou pior situação.

Encarado o fenômeno da perspectiva da comunidade que autoriza, incentiva, obriga e, conforme o grau de adiantamento, disciplina essa reação, aí encontraremos sempre presente a consciência do seu valor social.

Alega-se que a vingança privada não pode considerar-se a primeira manifestação de um Direito repressivo, porque "é puramente pessoal e a sociedade permanece estranha e indiferente a ela" (v.g., Cuello Calón, Derecho Penal, I, p. 55). $\mathrm{O}$ asserto não é, pelo menos, inteiramente correto. $\mathrm{A}$ moral primitiva, em boa parte envolvida por toda uma roupagem mística, impõe a vindita, às vezes até como imperativo sagrado. A opinião pública constrange a vítima e 
os seus a reagirem, porque sente que a impunidade do ofensor representaria uma ameaça para o equilíbrio, a paz, a integridade sociais. A praxe estabelece as hipóteses, as modalidades, os limites da reação cabível em cada caso. Aí está a ordem jurídica calcada nos costumes, nas crenças religiosas, brotando da consciência de todos e que exige a própria conservação. Simplesmente, por força das limitações do Poder porventura existente, ou devido à sua falta, deixa-se a cargo dos lesados a tarefa repressiva.

O Direito assim constituído será forçosamente esquemático, nebuloso, mas nem por isso deixa de representar um instrumento de conservação da ordem pública. A reação não fica entregue ao inteiro alvedrio da vítima, porque resulta de imposição do pensamento coletivo. Em conseqüência, o que a História mostra existir em toda comunidade primitiva não é a simples faculdade de vingar-se o ofendido ou seu grupo, mas o dever de fazê-lo.

$\mathrm{O}$ que varia é o modo de realizar-se a vingança. Se, num primeiro momento, permanece em larga margem entregue à discrição da vítima, o progresso neste terreno consiste em restringir-se cada vez mais a liberdade com que é exercida: na medida em que se aperfeiçoa a organização coletiva, da anárquica vingança privada, emotiva e geradora de excessos, o aparecimento de um Poder central leva inevitavelmente ao seu cerceamento. Evolui-se para o talião, para a composição pecuniária; opõem-se limites à intensidade da reação, indicam-se aqueles que poderão sofrê-la; e chega-se afinal à substituição da vingança pela pena, a cargo exclusivamente do Poder Público.

Esse, em linhas gerais, o processo seguido pela repressão criminal dentro de cada grupo. 0 que permanece incontroladas são as relações vindicativas entre grupos diferentes, porque as recíprocas ofensas e as conseqüentes respostas participam do crônico estado de beligerância que entre eles normalmente se mantém. 
11. Direito Penal, Direito Civil. Resta verificar, por derradeiro, se tudo isto que vimos descrevendo poderá compor o conteúdo de um autêntico Direito Penal.

"Desde a origem das sociedades", lembra Jules LorseLEUR, "encontram-se em toda parte castigos aplicados às faltas individuais, como meio de preservação para a família humana" (Les Crimes et les Peines dans l'Antiquité et dans les Temps Modernes, p. 2). Devemos acrescentar mesmo que o Direito repressivo constitui historicamente a primeira manifestação jurídica dos povos. E aqui entramos em tema assaz delicado, que só abordaremos de passagem.

Nota-se, de fato, que as regras consuetudinárias dos povos pré-letrados se apresentam carregadas de sanções e que outrotanto sucede nos primeiros corpos legislativos escritos que conhecemos, onde avulta o teor punitivo.

Não se pode explicar o fenômeno, como pretendem alguns, pela maior brutalidade do homem primitivo, o que o levaria à fácil prática de atos ofensivos; nem com o supostamente elevado número de casos de indisciplina social que caracterizaria a má organização das sociedades bárbaras, como querem outros, pois verificamos que nada disso é exato.

O que sucede é que, quanto mais incipiente se revela uma cultura, menos ensejo há para declarar-se o que hoje chamaríamos Direito Civil: devido à pobreza dos seus esquemas de relações pessoais, uns poucos costumes se revelam suficientes para disciplinar a vida do agregado. São tradições, convencionalismos, tabus, que têm como pano de fundo concepções místicas ou que se originam da experiência. Transformam-se em mores, que, sob a forma de usos e ideologias prescritivas, impregnam a consciência geral e aos quais todos prestam natural e inconsciente obediência. A regulamentação da vida, assim, se estabelece com independência de diretrizes criadas pelo Poder central ou para que existam, precindem de qualquer expressa 
declaração da coletividade. É nesses usos e costumes que se acha o Direito Civil, de modo latente.

No momento, porém, em que certa comunidade evolui e as suas formas de coexistência se vão tornando mais complexas - troca de utilidades, compra e venda, partilha de heranças, relações de trabalho, etc., - cresce a necessidade de se editarem normas que as regulamentem, inclusive estatuindo os correlatos direitos e obrigações (cfr. Montesquieu, Do Espírito das Leis, livro XVIII, caps. XI a XIII).

Nos graus inferiores de civilização, quase só se compreende uma tomada de posição do grupo quando os mores são infringidos. Então, sim, - inclusive por motivos "religiosos", ou místicos, - cumpre que a entidade governamental, quando existe, ou os membros do bando estabeleçam concretamente a solução do problema, o que fazem impondo as correspondentes sanções. Dai o fato histórico de que os primeiros rudimentos de atividade jurídica apenas venham a manifestar-se, ou o façam prevalentemente, com escopo punitivo.

Além disso, no mundo jurídico arcaico se torna relativamente extenso o papel reservado ao Direito Penal porque assuntos dos mais corriqueiros, desde que amparados pela tradição, ou por tabus, se transformam em obrigações seríssimas.

Nas sociedades com algum adiantamento, faz-se outrossim a divisão entre crimes de natureza pública e de natureza privada (parte dos quais vem depois a integrar o campo civil). Os delitos públicos justificam a interferência de um órgão superior, para julgar e impor penas, enquanto a reação contra os de qualidade privada costuma ficar a cargo da vítima.

Nos casos menos graves, a reação consistirá em mera sanção moral, gerando difusa reprovação da coletividade. Nos mais sérios, poderá haver uma sanção ritual, que torne o individuo impuro, com perigo para si próprio e para os 
que com ele mantenham contato, o que gera às vezes o seu apartamento da comunhão social; ou se chegará a verdadeiros castigos, de variada qualidade, como sanção retaliatória. Em se tratando de delitos privados, os povos mais atrasados deixam à discrição da vítima responder à ofensa, e até mesmo a compelem a assim proceder, sob pena de desonra. Quando, porém, se firma a posição do Poder Público como intermediário, a sanção nessas hipóteses assume a forma compensatória, ou restitutiva: como vingança equivalente ao mal sofrido (talião) e, depois, como ressarcimento pecuniário.

\section{Obras consultadas}

Alimena, Bernardino, Principii di Diritto Penale, vol. I, Nápoles, 1910. Badestra, Carlos Fontán, Tratado de Derecho Penal, vol. I, B. Aires, 1966.

BARNETT, James H. e Brown, G. Gordon, Organização Social e Estrutura Social, em Donald Pierson, Estudos de Organização Social, S. Paulo, 1970.

C.alón, Eugenio Cuello, Derecho Penal, tomo I, 9. a ed., Barcelona, 1948. CARNELUTTI, Francesco, Teoría General del Delito, trad. esp., Madri, 1941.

CARREL, Alexis, O Homem, esse Desconhecido, trad. port., Porto, s/d. Cooley, Charles H., A Sociedade e o Individuo, em D. Pierson, Estudos de Organização Social, S. Paulo, 1970.

- Grupos Primários, idem.

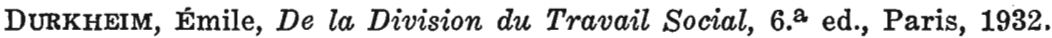

FARIs, Ellsworth, A Natureza e Significacão dos Mores, em D. Pierson, Estudos de Organização Social, S. Paulo, 1970.

- Atitudes Sociais, idem.

- Grupos Primários: Essência e Acidente, idem.

Fauconnet, Paul, La Responsabilité, Paris, 1928.

FkRRI, Enrico, Princípios de Derecho Criminal, trad. esp., Madri, 1933.

- Sociología Criminal, trad. esp., Madri, s/d.

Fuorian, Eugenio, Trattato di Diritto Penale, vol. I, Milão, 2.a ed.

Frazer, James, Magie et Religion, em Histoire Générale des Religions, public. sob direção de Maxime Gorce e Raoul Mortier, tomo V, Paris, 1951. 
FREUD, Sigmund, Totem e Tabu, trad. port. de J. P. Porto-Carreiro, Rio, s/d.

Fromm, Erich, Psicanálise da Sociedade Contemporânea, trad. port., Rio, 1970.

Garcia, J. Alves, Princípios de Psicologia, 3.ª ed., Rio, 1964.

Garofalo, R., La Criminología, trad. esp., Madri, 1912.

Goldenweiser, Alexander, Totemismo, em D. Pierson, Estudos de Organização Social, S. Paulo, 1970.

Hentig, Hans von, Criminología, trad. esp., B. Aires, 1948.

- La Pena, trad. esp., Madri, 1967.

Hollingshead, A. B., Controle Social, em D. Pierson, Estudos de Organização Social, S. Paulo, 1970.

Jung, C. G., Tipos Psicológicos, trad. port., Rio, 1967.

KeLSEN, HANS, Società e Natura, trad. it., Turim, 1953.

Kimberg, OLOF, Les Problèmes Fondamentaux de la Criminologie, trad. franc., Paris, 1959.

Kroeber, A. L., Casta, em D. Pierson, Estudos de Organização Social, S. Paulo, 1970.

LÉvi-Strauss, Claude, Anthropologie Structurale, Paris, 1969.

- La Pensée Sauvage, Paris, 1969.

LÉvy-Bruhl, Lucien, La Mentalité Primitive, $14 .^{\text {a }}$ ed., Paris, 1947.

Linton, RAlPH, O Homem: uma Introdução à Antropologia, trad. port., S. Paulo, 1970.

Liszt, Franz von, Tratado de Direito Penal Alemão, trad. port., Rio, 1899.

LoISEleur, Jules, Les Crimes et les Peines dans l'Antiquité et dans les Temps Modernes, Paris, 1863.

Lombard, Grovanni, Sociologia Criminale, Nápoles, 1944.

Jombroso, Cesare, L'Uomo Delinquente, vol. I, Turim, 1896.

LowIE, RoBert, Traité de Sociologie Primitive, trad. franc., Paris, 1935.

Lowie, RoBert H., Organização Social, em D. Pierson, Estudos de Organização Social, S. Paulo, 1970.

Malinowski, Bronislaw, Crimen y Costumbre en la Sociedad Salvaje, trad. esp., Barcelona, 1969.

- Estudios de Psicología Primitiva, trad. esp., B. Aires, 1949.

Montesquieu, Do Espírito das Leis, trad. port., S. Paulo, 1962.

Pareto, Vilfredo, Traité de Sociologie Générale, trad. franc., Paris, 1932-33.

Parmeise, Maurice, Criminología, trad. esp., Madri, 1925. 
Peña, Federico Puig, Derecho Penal, vol. I, 5. ${ }^{\mathrm{a}}$ ed., Barcelona, 1959. Pigrson, Donald, Estudos de Organizaçãa Social, trad. port., S. Paulo, 1970.

Quirós, Constancio Bernaldo DE, Criminología, México, $2 .^{\mathrm{a}}$ ed., 1955.

RadCliffe-Brown, A. R., Direito Primitivo, em D. Pierson, Estudos de Organização Social, S. Paulo, 1970.

- Estrutura Social, idem.

- Sanções Sociais, idem.

RAGlan, LoRD, Le Tabou de l'Inceste, trad. franc., Paris, 1935.

REDFIEID, RoBert, A Sociedade de Folk e a Cultura, em D. Pierson, Estudos de Organização Social, S. Paulo, 1970.

Siches, Luis Recaséns, Tratado de Sociologia, trad. port., Porto Alegre, 1968.

Soler, Sebastian, Derecho Penal Argentino, tomo I, B. Aires, 1967.

Sorokin, PITIRIM A., Sociedade, Cultura e Personalidade, trad. port., Porto Alegre, 1968.

Sumner, William Graham, Folleways, Mores e Instituições, em D. Pierson, Estudos de Organização Social, S. Paulo, 1970.

Thot, LAdislao, Historia de las Antiguas Instituciones de Derecho Penal (Arqueología Criminal), La Plata, 1940.

WARNER, W. Lloyd, Casta e Classe, em D. Pierson, Estudos de Organização Social, S. Paulo, 1970. 